\title{
Explaining Successes and Failures of River Basin Committees in Brazil*
}

\author{
by Léo Heller \\ Universidade Federal de Minas Gerais, Brazil
}

\begin{abstract}
(Abers, Rebecca Neara and Keck, Margaret E. Practical Authority: Agency and Institutional Change in Brazilian Water Politics. New York: Oxford University Press, 2013)
\end{abstract}

A new political-institutional framework for water management was inaugurated in Brazil with the promulgation of Federal Law no 9.433 of 1997. The model defined by the legislation was the result of a complex debate between political agents, specialists and service users, and generally received very positive reactions celebrating the fact that Brazil was carrying out a reorganisation of the sector attuned to contemporary global trends - more horizontal, decentralised, participatory and... effective. This model would allow for the environmental, economic, political, social and territorial dimensions of water use to be coordinated all at once. Hence, a river basin is defined as a territorial unit for implementing the water resources policy and a basin committee as a managing body for this territorial unit, with important responsibilities including conflict resolution, approval and monitoring of water resources plans, and setting up of systems for charging for water use.

A decade and a half after the launching of the National Water Resources System, there is already a large amount of assessments on the arrangement, especially of its greatest innovation, the participatory management model put into practice by means of the basin committees. The assessments published by the academic community, however, are far from being consensual. The authors oscillate between stating the democratic potential and innovative character of the committees and their belief in the superior nature of this participatory process compared to the previous model (aspects of this position can be

* http://dx.doi.org/10.1590/1981-38212014000100007 
found, for example, in JACOBI and MONTEIRO, 2006; JACOBI, 2009; PERKINS, 2011); a balanced view recognising its potential and the great challenges to its success (see, e.g., MARCON and PHILIPPI JR., 2007; TORTAJADA, 2001; VEIGA and MAGRINI, 2013; VICTORINO, 2003); and even more sceptical views, sometimes from opposite ideological positions, regarding the possibility of making "the participatory dream" brought about by the Law come true (see, e.g., BISWAS, 2008; BRANNSTROM, CLARKE and NEWPORT, 2004; MEDEIROS and SANTOS, 2009; SAITO, 2011; VALENCIO, 2009). This scepticism of the nature of participation in consultative and decision-making collegiate bodies is shared by a number of authors, who have pointed out the limited participation by civil society related, among other factors, to the quality, legitimacy and accountability of representation; the oligarchisation, co-optation and control of councils; and the suppression of conflicts and diversity of conceptions, intentions and projects (AGUIAR, 2011; CARNEIRO, 2005; MELLO, 2010; RAICHELLIS and EVANGELISTA, 2009; SPOSATI and LOBO, 1992).

Amid these many approaches, Rebecca Abers, from the University of Brasília, and Margaret Keck, from Johns Hopkins University, offer us an innovative, creative, rigorous and shrewd view of the participatory process of water management in Brazil in their 2003 book. It is work of the highest quality, of both content and the narrative style the authors chose to adopt. Brilliantly marrying (good) theory and empirical findings, they use water politics in Brazil as a gateway to analyse institutional change (defining institutions as "commonly accepted ways of doing things", p.03). For this, they "build" the concept of practical authority (defined by them as "a kind of power in which the capabilities to solve problems and recognition by others allows an actor to make decisions that others follow", p.07), which interacts with other concepts re-worked by the authors, such as that of entanglement (creating "new institutional arrangements in complex environments, where power is distributed according to different logics among multiple, heterogeneous organizations, often with ambiguously shared jurisdictions", p.04). If we were to place the book on an optimism-pessimism spectrum for participatory water management in Brazil based on the positions of the academic community referred to, the term "bias for hope" at the end of the acknowledgements and of the book itself would be the best way to classify it. Which is important for understanding how the authors weave their argument.

One of the book's strengths is how, in a constructivist fashion, almost like a sort of "grounded theory", the authors lead the reader through the path trodden by they themselves - a path of perplexity, absence of answers, reflection and of finding new explanations for what they observed in the 16 river basin committees assessed by them in the Watermark Project. In the Prologue, they make clear the question the book attempts to answer: why some river basin committees "got off the ground" (became "vibrant spaces 
for decision making and actions") "while others fizzled" (p. xvii, xix). They report that, in their empirical observations, they found that many of the committees were quite similar in terms of their contextual conditions "but experienced radically different outcomes" (p.xvii). This resulted in the conclusion that it is not the context that explains the differences, but "what the people involved did with the resources those contexts provided" (p. xvii). On the other hand, although some committees have already been in existence for several years, many still cannot be considered operational, which prevents their impacts on water management from being investigated. All of this led the authors to essentially rely on the functioning and institutional creation processes rather than placing an emphasis on the context or on outcomes. They anticipate their thesis at the end of the Prologue: "institutions come into existence when people act creatively... persuading influential others in their environments to engage with them in the practice of doing things differently" (p. xxi).

An interesting choice made by the authors, when explaining the committees' success or failure through the concept of "practical authority", is their position rejecting the agency-structure dichotomy. Although the manner in which the actors are involved in the participatory process is the explanatory framework adopted in the book, they argue that "institution builders are normally trying to create institutions because they want to change behaviours and not just minds" (p.17). These and other important theoretical debates can be found in the first chapter, which introduces the book.

Six other chapters follow. In chapters 2 and 4, the historical trajectory that shaped water politics in Brazil is described. Chapter 2 analyses the process of institutional reforms in the country in the 1980s and 1990s, from the legacy of the military dictatorship, and how these reforms produced entangled institutions. These entangled institutions are characterised by them as a "great deal of redundancy, overlap, and jurisdictional confusion" (p.33), fruit of the inertial forces of (strong) institutional reforms of the past. They identify four tensions, which embedded the country's political action in great complexity: "between central and regional governments, between executive centralism and a party fragmentation, between meritocracy and personalism, and between permeability and participation" (p. 39). This scenario shaped and brought determining factors to the water sector reform, which took place in the 1990s and is discussed in Chapter 3 ("How to Make an Unfinished Law"). In this part of the book, the authors assess the process of legislative reforms and the approval of the law that established the water resources policy in the state of São Paulo (1991) and of the national law (1997), showing how a set of different actions by a variety of protagonists caused an "excess of influential positions" (p. 56) and resulted in sometimes considerably ambiguous legal texts. They highlight, by means of an interesting diagram (p.77), how the several interest groups supported or opposed the 
four pillars of the national law: river basins as planning units; water pricing; participation by users and civil society; and management for multiple uses. The position of the energy sector, which opposed the new legislation for fear of losing its historical control over the water resources policy in the country, given the great importance of hydroelectric power in the national energy matrix, is an important reference in this diagram.

Chapter 4 deals with the implementation of the new legal and institutional framework and identifies much misalignment between the new legislation, enthusiastically supported by the main actors of the water resources sector but vague in the definition of its instruments, and the frailty of its implementation. The authors posit possible explanations for the low incentive for powerful actors to invest in the new management model and in support of the creation, institutionalisation and strengthening of new forms of organisation for water resources management, such as the basin committees. One of them would be that influential water specialists might have been "caught up in the liberalizing narrative of the 1990s" (p. 109) [would they have previously held different positions?]. They illustrate this point with an enlightening report by a renowned specialist, in which he expresses his lack of belief in the capacity of the State to carry out enforcement and the need for it to be substituted by self-regulation strategies by stakeholders.

The remaining chapters - 5, 6 and 7 - describe the 16 empirically investigated cases to varying degrees of depth, although previous chapters deal with some of their aspects, e.g. an analysis of the implementation of water charges in one of the basins. Chapter 5 deals with the process of creating the committees ("Becoming Committees"), stating that some of them were "false starts" (p. 113), especially because of the absence of groups of people willing to take on the initiative, or because the social agents did not see any advantages in approaching the problems from the perspective of water basins. However, they highlight that a surprising number of committees had at least one highly motivated person, inspired by the idea of connecting people, the possibility of greater effectiveness in solving problems, or by the notion of participation as a driver for strengthening democracy (p. 113). The actions by two of the committees locked in conflicts involving interbasin water transfers, of which that of the São Francisco River is emblematic, are dealt with in chapter 6 ("Power, Perseverance and Struggles") and are a powerful illustration of how actors mobilise their powers of influence in acute situations. The most important of the book's arguments, the "slow accumulation of practical authority" (p. 115), is the subject of Chapter 7 ("Building Practical Authority from Outside the State"), also dedicated to two basins and emphasising the role of leadership in making practical authority dynamic.

With this content, I am fully convinced of the important role that the book can play in aiding a better understanding of the tortuous flows of water and its politics in Brazil. There is an impressive amount of statements, documents and specific literature, which 
shed light on the situation of important cases of water resources management in Brazil by means of basin committees. No less important is the historical, critical examination of this process. I believe this book to be indispensable literature for those interested in water politics in Brazil, as it allows for a fruitful dialogue with the literature mentioned in the initial part of this review. But fundamentally, it is an inspiring read for those attentive to good research production and how it can be narrated with creativity and rigour. Research with the ability to avoid the easy route of working with a static object, to develop previously unmovable questions and to test them in a linear investigation process, but with the capacity to mould itself to empirical data with perspicacity and to formulate and reformulate its questionings, its presuppositions, its theoretical basis and its methodological framework, resulting in a piece of undisputable quality. The authors' surgical precision in their use of quotations from different disciplinary fields draws one's attention, revealing their erudition.

My familiarity with the experience of basin committees is very "domestic". I am a professor of the Universidade Federal de Minas Gerais, which hosts the Manuelzão Project, which in turn drives the committee of the Velhas River basin, one of the cases used as an illustration of practical authority in Chapter 7. My perception is that, truly, the Velhas River Committee would not have had its genesis and strong momentum had it not been perseveringly stimulated by this Project. The agency mattered in this case, enabling an outcome closer to that envisaged by the legislation. However, a zoom into it would reveal some concerns regarding the manner in which the process is taking place. One is certainly the Project's massive financing with public funds from the state government, which may have brought about an excessive proximity between the two parties, possibly leading to their agendas overlapping (for an evaluation of a case in which the Project adhered to the interests of the state government to the detriment of those of a municipal government, see NUNES et al., 2011). Uncertainties regarding the Project's continuity and the committee's feasibility, should the Project cease to have its current strong presence, are another point worthy of consideration. That is, the contingency of the situations experienced by the association between Manuelzão and the Velhas Committee does not provide any security for making a projection of the committee's future.

The last paragraph of the Conclusion recognises that the book's lack of closure can only be accepted if we consider that "things are not always as they seem and that people... always act on assumptions about our physical and relational settings that are subject to change" (p. 209). This contingent nature of processes, and, in some cases, of outcomes, is perhaps constitutive of the concept of the influence of practical authority in the life of basin committees in Brazil, which brings lessons for researchers and managers about keeping alive, albeit vigilantly and cautiously, the "bias for hope". 


\section{References}

AGUIAR, Marluce Martins de (2011), Gestão dos serviços de abastecimento de água e esgotamento sanitário: a participação social em três modelos institucionais no Espírito Santo. PhD Thesis, Universidade Federal de Minas Gerais.

BISWAS, Asit K. (2008), Integrated water resources management: Is it working? Water Resources Development, vol. 24, no 01, pp.5-22.

BRANNSTROM, Christian; CLARKE, James and NEWPORT, Mariana (2004), Civil society participation in the decentralisation of Brazil's water resources: Assessing participation in three states. Journal of Tropical Geography, vol. 25, nº 03, pp.304-321.

CARNEIRO, Eder Jurandir (2005), A oligarquização da "política ambiental" mineira. In: ZHOURI, A.; LASCHEFSKI, K. and PEREIRA, D.B. (org.), A insustentável leveza da política ambiental: desenvolvimento e conflitos socioambientais. Belo Horizonte: Autêntica, p. 65-88.

JACOBI, Pedro R., and MONTEIRO, Fernando (2006), Social capital and institutional performance: methodological and theoretical discussion on the water basin committees in metropolitan São Paulo - Brazil. Ambiente \& Sociedade, vol. 9, nº 02, pp.25-45.

JACOBI, Pedro R. (2009), Governança da água no Brasil. In: RIBEIRO, Wagner Costa (org.), Governança da água no Brasil: Uma visão interdisciplinar. São Paulo: Annablume/ Fapesp/CNPq, pp.35-60.

MARCON, Giuliano and PHILIPPI JR., Arlindo (2007). Avaliação da política estadual de recursos hídricos de São Paulo nas bacias hidrográficas dos Rios Piracicaba, Capivari e Jundiaí. Revista Brasileira de Recursos Hídricos, vol. 12, nº 03, pp.199-209.

MEDEIROS, Yvonilde and SANTOS, Elisabete. (2009), Participação social no gerenciamento dos recursos hídricos: a bacia do rio São Francisco. In: RIBEIRO, Wagner Costa (org.), Governança da água no Brasil: Uma visão interdisciplinar. São Paulo: Annablume/ Fapesp/CNPq, pp.91-110.

MELLO, Maíra Crivellari Cardoso (2010), Participação social em conselhos municipais de saneamento: o caso do COMUSA Belo Horizonte. Master Dissertation, Universidade Federal de Minas Gerais.

NUNES JR., T.T.; HELLER, L.; SILVA, P.L.; REZENDE, S. and RADICCHI, A.L.A. (2011), Prestação dos serviços de água e esgotos em Sete Lagoas - MG: o SAAE é nosso ou que venha a COPASA. Revista Brasileira de Estudos Urbanos e Regionais, vol. 12, $\mathrm{n}^{\mathrm{o}}$ 01, pp. 119-142.

PERKINS, Patricia E. (2011), Public participation in watershed management: International practices for inclusiveness. Physics and Chemistry of the Earth, vol. 36, pp.204-212.

RAICHELIS, R. and EVANGELISTA, A.C. (2009), Sociedade civil, questão social e relações internacionais na cidade de São Paulo. In: Wanderley, L.E. and R. RAICHELIS (org.), A cidade de São Paulo: relações internacionais e gestão pública. São Paulo: Educ.

SAITO, Carlos A. (2011), As mútuas interfaces entre projetos e ações de educação ambiental e de gestão de recursos hídricos: Subsídios para políticas de estado. Ambiente \& Sociedade, vol. $14, \mathrm{n}^{\mathrm{o}} 1, \mathrm{pp} .213-227$. 
SPOSATI, A. and LOBO, E. (1992), Controle social e política de saúde. Cadernos de Saúde Pública, vol. 08, nº 4, pp. 366-378.

TORTAJADA, Cecilia (2001) Institutions for Integrated River Basin Management in Latin America. Water Resources Development, vol. 17, nº 03, pp.289-301.

VALENCIO, Norma F.L.S. (2009), Governança das águas: A participação social como quimera. In: RIBEIRO, Wagner Costa (org.), Governança da água no Brasil: Uma visão interdisciplinar. São Paulo: Annablume/Fapesp/CNPq, pp.61-90.

VEIGA, Lilian Bechara Elabras and MAGRINI, Alessandra (2013), The Brazilian water resources management policy: Fifteen years of success and challenges. Water Resources Management, vol. 27, pp.2287-2302.

VICTORINO, Valério Igor P. (2003), Monopólio, conflito e participação na gestão dos recursos hídricos. Ambiente \& Sociedade, vol. 06, nº 02, pp.47-62. 